\title{
Tasty book: scientific method with sensible flavor
}

Livro para saborear: método científico regado a sensibilidades

Libro para disfrutar: método científico con sensibilidades

Livre à savourer: méthode scientifique plaquée avec sensibilité

Tati Costa[1]

\section{ALVES, Rubem. Variações sobre o prazer: Santo Agostinho, Nietzsche, Marx e Babette. São Paulo: Editora Planeta do Brasil, 2011. 188 p.}

\author{
To my knowledge, there is only one place in the \\ entire universe where pure thought is capable of \\ moving matter. This place is the body. In the body, we think \\ about a stew and our mouths fill up with water. (p. 144)
}

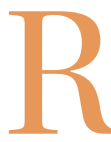

eviewing a book by Rubem Alves is a tasty challenge for the quality of his writing and the erudition of his knowledge. Reviewing with the purpose of academic circulation targeting historical knowledge is like adding a pinch of pepper to spice up the challenge. For the life experience narrated by the author, then 77 years old, carries a provocation to the fact that educational, academic and scientific environments ignore the sensitive aspect of knowledge and the dimensions of love, pleasure, desire, and joy.

Fortunately, in human sciences, some experiences with history of the present have been dedicated to similar challenges. For instance, the history of sensibilities has been trailed with wisdom; the art of good conversation has been cultivated for some time in research studies on oral history, and, in cultural history, we dwell on the arts and artists of poetry and literature, music, culinary, and imagery in search of the economies of desire present there.

Right from the beginning, the author suggests approximations between the construction of knowledge and gastronomy by highlighting the coincident etymologic roots of saber (to know) and sabor (flavor). He also recalls that, a long time ago, when a dish was tasty, people used to say: "this food knows well". 
The book transits through variations in which the objects of analysis are re-addressed from different points of view in essayistic chapters. In addition to the preface written by the author himself, 12 essays vary considerably in regards to narrative structure. The titles were composed with a remarkably good humor combined with critical provocations. For instance, the footnotes (notas de rodapé) are called notas de canapé (finger food notes), a term that Rubem Alves considers more appropriate because they should be "small and tasty things, some sweet, others spicy, that incite the appetite and are served at the height of the party".

He draws attention, above all to matters of history and memory, which significantly occupy the scene in current historical studies. In this sense, my observations discuss the methodological potential of the book in question as a contribution to research in cultural History, History of the present, and oral History. Furthermore, the book offers a fine ensemble of classical authors, a morsel for those who research appropriations and reading approaches concerning Nietzsche, Marx, Fernando Pessoa, Bachelard, Paulo Freire, Wittgenstein, Manoel de Barros, Guimarães Rosa, and William Blake, among others.

Old age is the place from which the author speaks (or writes): "The awareness of death gives us a wonderful lucidity". The singularity of this stage of life informs us about the author himself and the categories attributed to him: winner of the Jabuti Prize in 2009, professor emeritus at Universidade Estadual de Campinas (Unicamp), educator, poet, chronicler, story teller, essayist, theologian, and psychoanalyst.

When he talks about aging, Alves refers to human beings metamorphosing over the course of time, the historical process of body changes, and perspectives about this experience. Considering the frequent participation of elderly people in oral History, the author's testimony suggests useful ingredients to epistemological areas interested in considering the elaborations, narrative compositions, and self-perception processes that operate during the production and registering of oral accounts, as pointed out by Walter Benjamin, ${ }^{5}$ Alessandro Portelli, ${ }^{6}$ and Eduardo Coutinho. ${ }^{7}$

Another important insight is that the conduction of interviews is an act of sensibility that requires a taste for good conversation, and an epistemology about the pleasure of good conversation is precisely one of the elements present in this work. An encounter between the person who researches life stories and the person who narrates is a space of art and wisdom where the pleasure of the body is revealed as essential. The dimension of the body as an element of knowledge has fundamental importance for those who work with the topic of memory in history. Let us remember, for instance, Henri

${ }^{3}$ Rubem Alves, Variações sobre o prazer: Santo Agostinho, Nietzsche, Marx e Babette, São Paulo, Editora Planeta do Brasil, 2011, p. 7.

4/dem, Ibidem, p. 9.

${ }^{5}$ Walter Benjamin, Magia e técnica, arte e política: Ensaios sobre literatura e história da cultura. São Paulo, Brasiliense, 1987.

${ }^{6}$ Alessandro Portelli, "A Filosofia e os Fatos. Narração, interpretação e significado nas memórias e nas fontes orais," Tempo, vol. 1, n. 2, Rio de Janeiro, 1996, p. 59-72.

'Eduardo Coutinho, "O cinema documentário e a escuta sensível da alteridade", Projeto História, n. 15, São Paulo, 1997, p. 165-191. 
Bergson's discussion in "Matéria e Memória" ("Matter and Memory"), ${ }^{8}$ addressed in Ecléa Bosi's debate ${ }^{9}$ about society and memory in recollections of elderly people, and complemented in a dialogue with Paul Ricoeur ${ }^{10}$ about memories shared by "close" people. Considering the several operations that occur between individual and collective memory, it is through the body that the recollection of a lived experience is inscribed into a person.

\section{Old age is the place from which the author speaks (or writes): "The awareness of death gives us a wonderful lucidity".}

But the memory feeds both on recollections and forgetting, a theme that receives a specific essay by Rubem Alves, titled "O esquecimento: Barthes (ou 'Me esqueci do sabido para me lembrar do esquecido')" ["Forgetting: Barthes (or 'I forgot what was known to remember what was forgotten')]. The essay contains some proposals produced by Barthes in his old age, when he dedicated himself to research and experimentation. Here lies another important lesson to those who work with oral History:

if I want to live, I must forget that my body is historical, I must fling myself at the illusion that I am contemporary to the current young bodies, and not to my past body. ${ }^{11}$

The relationship between knowledge and the phases of life, the target of Rubem Alves' reflections, outlines a route of approximation between the work in question and history making in contemporaneity:

There is an age when one teaches what one knows, but another age follows in which one teaches what one doesn't know: that is called researching.

Is this not an inspiration for the history of the present? A history written based on the comprehension that this science reached the "edge of the cliff", and which focuses on the very process of research unfolding, its paths and dead ends, choices and disposals, that is, the "historiographical operation" per se, taken as the object of analysis.

At this point, we are guided towards a dialogue with the author's conception of science, i.e. the shock between the limits of objectivity in relation to subjectivity and the body's knowledge, a universe beyond "logical and rational" knowledge. After all inquires Rubem Alves, what makes a good stew?

\footnotetext{
"Henri Bergson, Matéria e memória: ensaio sobre a relação do corpo com o espírito, 4. Ed., São Paulo, WMF M. Fontes, 2010.

`Ecléa Bosi, Memória e sociedade: lembranças de velhos, 3. Ed., São Paulo, Cia das Letras, 1994.

10 Paul Ricoeur, A memória, a história, o esquecimento, Campinas, Editora da Unicamp, 2007.

${ }^{1 R}$ Roland Barthes apud Rubem Alves, Variações sobre o prazer: Santo Agostinho, Nietzsche, Marx e Babette, São Paulo, Editora Planeta do Brasil, 2011, p. 52.
} 
A recipe book is not a guarantee of success without the cook's experience. It is here that the issue of a scientific method dipped in sensibility is inserted: the gathering of ingredients will result in a good stew only if it is mouth-watering. And, for this purpose, it is imperative to rely on the knowledge of the body, which spans from a memory of the ideal taste of a stew, passing through the wisdom required to sprinkle seasoning all the way to mixing the ingredients until it is ready.

Inspiration, this element we all know (or seek, at least), is essential in choosing the dish to be prepared, the quantity and quality of the ingredients, and in the moments of lowering or increasing the flame. In this way, Rubem Alves leads us towards the paradox of the (im)possibility of a method of writing or inspiration. Nevertheless, this point turns the work in question into an inspiring provocation! Concerned that writing should be as pleasurable as a good conversation, Alves teaches us about the relation between orality and writing, and suggests a few narrative seasonings that aid in telling a good story:

A scientific paper is this: an account of the path followed in order to go from the starting point to the ending point. This is called method. But the body does not understand the language of method. Methods are rational procedures. And the body is a musical being. "The organism is a melody to be sung," says Merleau-Ponty citing biologist Uexküll. ${ }^{12}$

Even though Rubem Alves defends writing "against the method", with permission and a profound respect for the author, I dare to read a methodological proposal in the book I have in my hands. It is neither a linear, objective or rational method, such as proposed by Cartesian science, nor the Hegelian method of history. In my view, it is a methodology of inspiration and sensibilities - considering that this latter suffix can be a way of translating a broader sense of knowledge into words.

The discussion of methods and methodologies is in current demand. Several areas of science went through an epistemological "crisis" or "turn",13 especially during the transitions and revolutions that characterized the $20^{\text {th }}$ century. After what was named the linguistic turn, the author's role in the production of scientific knowledge has been recognized as a key question. If we attempt to pinpoint the emergence of this topic, an interesting debate

\footnotetext{
${ }^{12}$ Rubem Alves, Variações sobre o prazer: Santo Agostinho, Nietzsche, Marx e Babette, São Paulo, Editora Planeta do Brasil, 2011, p. 17.

${ }^{13}$ Among possible approaches, I mention authors who situate this topic in their study areas, while pointing out that these are choices within a varied and tasty menu! Roger Chartier debates history between certainties and disquietude; Fritjof Capra dedicates himself to a dialogue between theories in physical and biological sciences, and social and political systems; Beatriz Sarlo reflects upon the emergence of a culture of memory since the subjective turn. Cf. Roger Chartier, À beira da falésia: a história entre certezas e inquietudes, Porto Alegre, Ed. UFRGS, 2002. Fritjof Capra, As conexões ocultas: ciência para uma vida sustentável, São Paulo, Cultrix, 2005. Beatriz Sarlo, Tempo passado: cultura da memória e guinada subjetiva, São Paulo, Cia das Letras; Belo Horizonte, UFMG, 2007.
} 
will unravel, reuniting temporalities through the works written by Walter Benjamin, ${ }^{14}$ Roland Barthes, ${ }^{15}$ Michel Foucault, ${ }^{16}$ and Giorgio Agamben. ${ }^{17}$ In this manner, the challenge of how to operate this transition, à la Deleuze and Guattari, from the "tree of knowledge" to the "rhizome" is posed. ${ }^{18}$

It is through a sensibly rhizomatic text composed with images that a methodology for the construction of sensitive knowledge is exposed: in the way one writes, followed by good music; in pieces of advice, "to learn logic, read poetry;" in the one thousand and one different ways the author finds to insert a dialogue with authors and theories or, as he likes to say, conversations with authors. He even offers a "recipe" to find inspiration through Nietzsche's description:

Suddenly, with indescribable certainty and subtlety, something becomes visible, audible, something shakes us in our depths and tosses us on the ground... We don't search, we listen. We don't ask or give, we accept. Like lightning, a thought is illuminated, with necessity, with no hesitation in regards to its form. ${ }^{19}$

With the metaphor "ideas are ballerinas, inspiration is the soloist," the text is composed organically as in a corps de ballet. The cadence of scientific knowledge that considers inspiration as a methodological element is tuned, for instance, with Durval Muniz Albuquerque Jr's work ${ }^{20}$ when Alves affirms that history is the art of "inventing" the past, and with João-Francisco Duarte Jr's defense ${ }^{21}$ of an education for (of) sensibility. Both authors mentioned above punctuate a metamorphosis of the very view of truth over the course of the history of science: more than absolute, truth figures as a horizon of possibilities when the relationship of interdependency between the reality observed and its registering by the observer is taken into consideration.

Rubem Alves draws on the limits of language in order to address the experience of sensibility and the problems that occur when science, strictly rational, ignores or silences an important gamma of knowledge present in the body and that is not expressed through purely logical words. As a path towards pleasure, Alves proposes the methodology used in culinary arts, that is, the awareness of desire and the means to produce it. In this sense, the function of intelligence "is to organize power in a way that it transforms itself into a bridge between desire and its object".22

\footnotetext{
$\overline{{ }^{14} \mid}$ refer here to the 1934 essay "O autor como produtor" ("The author as producer") in Walter Benjamin, Magia e técnica, arte e politica: Ensaios sobre literatura e história da cultura. São Paulo, Brasiliense, 1987.

${ }^{15}$ Roland Barthes, "A morte do autor" (1968), In: __. O rumor da língua. 2. Ed., São Paulo, M. Martins, 2004, p. 65-78.

${ }^{16}$ Michel Foucault, O que é um autor?, 4. Ed., Lisboa, Passagens; Vega, 2000

${ }^{17}$ Giorgio Agamben, “O autor como gesto," In: __. Profanações, São Paulo, Boitempo, 2007, p. 55-62.

${ }^{18}$ Giles Deleuze; Felix Guatari, "Introdução: Rizoma," Mil platôs: capitalismo e esquizofrenia, vol. 1, Rio de Janeiro, Ed. 34, 1995, p. 11-37.

${ }^{19}$ Rubem Alves, Variações sobre o prazer: Santo Agostinho, Nietzsche, Marx e Babette, São Paulo, Editora

Planeta do Brasil, 2011, p.23.

${ }^{20}$ Durval Muniz Albuquerque Jr., História. A arte de inventar o passado, Bauru, Edusc, 2007.

${ }^{21}$ João-Francisco Duarte Jr., O Sentido dos Sentidos: A Educação (do) Sensível, 4. Ed., Curitiba, Criar Edições, 2006.

${ }^{22}$ Rubem Alves, op cit., p. 147.
} 
In this sense, I highlight "Os saberes do corpo ("The knowledge of the body"), the sixth essay of the book, dedicated to a "Bergsonian" idea: the perception that we have of something is the perception of its effects on sensibility, a process that occurs in a very intimate way in the sphere of subjectivity. Besides accumulated, verified, and attested knowledge, there is a subjective level of knowledge elaborated by each person; for example, the way each person tastes the same mango. The experience is incommunicable, impossible to be translated into words, much less into verifiable data.

\section{The encounter between the person who researches life stories and the person who narrates is an space of art and wisdom. The dimension of the body as an element of knowledge has fundamental importance for those who work with the topic of memory in history.}

There are seven essays dedicated to what I risk calling an epistemology of sensitive knowledge, followed by five about the variations of pleasure. They are inspired by the common practice in music of composing "variations about the same theme". In addition to erudite pieces produced based on this modulation, blues and jazz jam sessions are on the same plane, but with a good dose of improvisation. In each essay, Rubem Alves composes a different variation about pleasure from the point of view of a specific knowledge area together with a central author.

The first variation, theology, relies on a longstanding text as its starting point: De doctrina christiana, written by Saint Augustine (354-430 A.D.). The second variation, philosophy, is a trans-literary conversation with Nietzsche, in which "Nietzschean" ideas are transposed to the text with a focus on the latter's specialty: going beyond the concern with things that can become words in search of the universe of the unspeakable, which is visible, audible, and sensitive. The third variation, economy, is the author's conversation with Marx in a bohemian environment drenched in beer and surrounded by cigar smoke. The fourth variation, culinary, approximates the themes of science and knowledge to the culinary sphere in conversations with cooks such as Babette.

The coffee in the essay Post scriptum is followed by a tasty mint-coated chocolate dedicated to the absence of love and pleasure in education. Based on my reading, from the point of view of History we must share this observation, since our occupation is linked to education in all schooling years, from elementary to post-secondary education. And, even when we do not dedicate ourselves directly to teaching, we concentrate on research, therefore 
producing knowledge that, in order to be meaningful, must address the public and function as a tool for knowledge.

The aftertaste that follows the reading of this delicious book is the flavor of a book written with pleasure. Metaphors for the art of writing, permeated by images of culinary and music, reveal the importance of personal experience and the power of sensibility for the conduction of research and the construction of scientific knowledge. For Rubem Alves, the first step is dreaming, making the body work for pleasure, more than for duty. That the teachers start dreaming and teaching how to dream... In view of this, I finish with a sentence by Euclides Sandoval, philosopher, writer, reader of Nietzsche and a teacher for 40 years, from elementary school to university Art departments, written in one of his journals: "Before a class, the teacher needs to sleep... And dream". 